York: Routledge, 2005) 98-111, p 111. See also Paulin, The Day-Star of Liberty: William Hazlitt's Radical Style (London: Faber and Faber, 1998).

12. Tom Paulin, "Spirit of the Age," The Guardian 5 April 2003 <http://books .guardian.co.uk/review/story/o,12084,929 528,oo.html>.

13. See http://www.williamhazlitt.org.

14. See, for instance, Robert Morrison, "Well-Feathered Thoughts," Essays in Criticism 52.3 (2002) 258-262.

15. Uttara Natarajan, [untitled review], The Review of English Studies, 240/59 (2008) 470-472.

16. Virginia Woolf, "William Hazlitt," in The Second Common Reader (New York: Harcourt, Brace \& World, 1960), 156-166, p. 166.

17. Charles Lamb, "The Two Races of Men," in The Works of Charles and Mary Lamb, ed. E. V. Lucas (London: Methuen, 1903), 22-27, pp. 26-7.

18. Seamus Perry notes this in his review of the volumes: "A man of singular opinions," TLS, 18 April 2008, p. 12.

19. Paul Johnson, "A Role Model for All Dictators," The Daily Telegraph 17 October 2004 <http://www.telegraph.co.uk/arts/ main.jhtml?xml=/arts/2004/10/24/bohaz2 4.xml\&sSheet=/arts/2004/10/24/bomain .html>.

20. Simon Brainbridge, Napoleon and English Romanticism (Cambridge: Cambridge University Press, 1995), p. 207. More recently, Paul Stock has written about Hazlitt's conscious use of Napoleon as an "ideological symbol" (Stock, "Imposing on Napoleon: The Romantic Appropriation of Bonaparte," Journal of European Studies 36.4 [2006] 363-388).

\section{Representability and Pathological Discipline}

Philippe-Alain Michaud, Aby Warburg and the Image in Motion, translated by Sophie Hawkes, foreword by Georges Didi-Huberman (New York: Zone Books, 2004)

Scholars who have tried to give an overall description of Aby Warburg's structure of theory have always faced enormous difficulties. He himself admitted the presence of a private overtone in all his works, something he called an "autobiographical reflex." 1 It is this private tone in Warburg's style; increasingly deviating from the accepted conventions of academic prose, with hints to meanings that were not explicitly stated, that has proved to be the most difficult challenge for scholars. These private dimensions may be further expanded by taking into consideration the huge amount of notes and drafts he never intended to see in print. ${ }^{2}$

The style of the few studies he edited is very dense and strict and the notes and drafts sometimes explore an embarrassingly private and relaxed sphere of a scholar's mind. The fact that the number of studies he published throughout his life is very small, there are many themes he only planned to write about, give his oeuvre an unfinished character, at the same 
time making it impossible to disregard the notes and drafts. Interestingly enough the way he constructed the structure of the famous library he founded and the criteria according to which he again and again re-arranged the books also add a lot to the understanding of his methods. In the foreword to the English translation of Philippe-Alain Michaud's Aby Warburg and the Image in Motion, Georges Didi-Huberman stresses that this is "the first book on Warburg to be written in French" (7), which is important because art historians such as Henri Focillon and Andre Chastel, who determined the scope of French art history in the last few decades, had neglected Warburg's theories.

Georges Didi-Huberman devotes much attention to the Warburgian term pathos and with a little twist of the etymological game to pathology (14). This association which in the light of the translation problems and the fact that Warburg spent almost six years in Kreutzlingen Clinic for "paranoid phantasies" and "psychomotor disorder" may seem a sensitive issue. ${ }^{3}$ Michaud, in a permanent debate with commentators on Warburg, 4 argues that his theoretical heirs developed a domesticated iconology based on the decipherment of symbols whereas he argues Warburg's project was remote from this level of positivist approach. 5
Warburg never laid down any theoretical basis for a study of art history. The thesis concerning what iconology means is based on his famous interpretation of the frescoes of the Salone dei Mesi in Palazzo Schifanoja, Ferrara he presented at the first art history conference in Rome in 1912, where he described his approach as an "iconological analysis." 6 Pathosformel (pathos formula) is a key concept in Warburg and is the epicentre Michaud argues of the whole system to be re-interpreted.

In opposition to Winckelmann's "tranquil grandeur," in $1893^{7}$ Warburg elaborated the idea that it was not the untroubled serenity of its majestic beauty- the motionless well-balanced body- that served as the model for the imitation of Antiquity "but rather the body caught up in a play of overwhelming forces." The model of sculpture is reversed with that of the dance, accentuating the dramatic and temporal aspect of the works rather than the tranquil and eternal features. What Renaissance artists derived from antiquity was not an association between substance and immobility but, on the contrary, they stressed tension and drama. They refused to identify with aesthetic categories in favour of ecstatic expressive formulae. These forces destabilize the figures rather than pulling them together: divine serenity that served as the model of ideal beauty was transformed into bacchantes (28). 
Up to this point Michaud's argumentation does not seem new in realizing Warburg's Nietzschean preoccupation with tension and ecstasy, irrupting the Apollonian equilibrium as a driving principle in the Renaissance, all commentators including Gombrich underlined it as his basic principle. ${ }^{8}$

Michaud's new approach is that he goes much beyond the mere recognition of Warburg's revolutionary idea. He claims that it is not only motion, movement and tension, but the presentation of their representability that Warburg aimed at: "a whole series of Renaissance artists and poets. seem to have used a work of Antiquity, including its deterioration, to express the phenomena of appearance and disappearance, seeking to reproduce not so much the figure depicted as the fact of figuration itself, and the pulsing presence and absence of conditioning it (72). Movements he explores become associated with the subject's entrance into image through the rites of passage and with dramatizations of his or her own appearance (32).

For Warburg, Michaud argues, symptom had a more complicated meaning than how it is usually understood: 9 symptom should be interpreted as an archaeological and simultaneously current implication in bodies represented revealing their innate pathetic capacities through movement. Starting from Warburg's theory of motion and movement, Michaud arrives at the conclusion that a kind of cinematic perception is basic in Warburg's thinking, which meant to re-establish the synchrony between image and discourse. "To join an image with a sound, a figure with a voice, such was the way precursors of cinema envisaged the recording and mechanical reproduction of movement before it was thought materially possible," he adds (39).

This is the point in the argumentation when the author starts to introduce parallels from other categories of imagery. Examples are taken from the history of the cinema to prove the presence of identical categories and similar visual perceptive capacities. Parallels are drawn with W. K. L. Dickson's Filmed Effigies and kinetographic scripts, the Japanese Kabuki theatre, the theories of the photo-cinematic images by Kracauer, Russian film theory and even with Jean-Luc Godard. These parallels and comparisons, though peculiar, are also exciting, but seem to lack the minimum expectations towards academic writing. The comparison with the Japanese theatre for example starts with the sentence: "Let us imagine he wanted to see Kabuki theatre" (271).

A really unique and exciting section of the book is chapter three where the Warburgian notion of motion is elaborated. In 1902 Warburg published two studies, both devoted to what he called 
"living art of portraiture": "The Art of Portraiture and Florentine Bourgeoisie" and "Flemish Art and the Florentine Early Renaissance."10 Warburg's scope is no longer how Italian Quattrocento artists and Flemish painters represented bodies agitated by external forces but rather how bodies are animated by inner principles.

Michaud's daring and unique approach reveals Warburg's novel treatment of his topic. In these two studies beyond the strict and scholarly style, we can really trace a structure of thought not revealed or unnoticed by earlier interpretations.

There is a definite wish to reconstitute the singular reality of the individual depicted through a montage of texts and images within the works themselves (similarly to Burchardt's attitude in his The Civilization of the Renaissance in Italy, a book Warburg regularly referred to). Michaud suggests there is a "direct relationship between model and painting which is not mediated by the artist, whose function thus becomes slightly blurred. In other words the painting is qualified not simply by its site but as a site" (125). There is a space created between the model and the painted surface putting the author of the work of art in a strange position. ${ }^{11}$

The most exciting part of the analysis is the chapter on "Three Portraits of Maria." Warburg in his study analyses three portraits of Maria Portinary: the so called Turin portrait by Hans Memling, the Paris portrait by Memling and the portrait on Hugo van der Goes' Uffizi triptych. In examining the signs of physical changes over the course of the three portraits Warburg, Michaud claims, applies the ancient medical technique of prognostics based on Pliny's Natural History. ${ }^{12}$ The painted surface becomes a transparent screen, a space between the model and the historian. The figures thus created are not immobile ones but rather figures delivered to the limits of time: "the stages of Maria's entry into the universe of representation reveal the spectacle of her physical deterioration" (131). According to Warburg the Portinary triptych, in the end, transforms Maria's image into a votive effigy. The movement of a single body is exposed "through a succession of juxtaposed images" (135). Maria (or rather her image) seems to travel from painting to painting.

Through the travel of the same model, Michaud argues, the same image gathers fractions of the modifications of the model's own fleshly being. Separate semantic essences are being created through a montage made up of cross sections of single works of art. The procedure of upholding the figure in its duration within the circles of representation is a passage leading from the world of things to that of images. The spectator has to give up passive 
contemplation in order to intervene actively in the representation.

Michaud's interpretation is not farfetched at all - Warburg really aimed at a very personal approach to pieces of art where the scholar or the spectator is invited to get into close and combinative relationship with the works of art. The analysis of Maria's portraits was facilitated by photographic reproduction which is an important element in Michaud's argumentation: he claims that Warburg's increasing use of photography tells us much about how he developed a cinematic way of visual conceptualization. In itself, the fact that the sequence is created through photographic representation may well lack all significance, since the three paintings theoretically could be put side by side at any time to represent the idea of juxtaposition.

Another weak point in Michaud's argumentation, in my view, is that his concept of "travelling" is definitely a linear movement, whereas the elements (the paintings) of this sequence can be mixed and changed any time (by nonlinear irregular motions). The facts that the paintings listed here are of different functions (portrait and altarpiece) and were painted by different artists (Memling and Hugo van der Goes) seem to have fallen outside Michaud's scope, not to mention aspects like artistic value or differences in material and size.
A few months after the publication of his study on the Florentine Intermedi festivities, "Warburg would discover the phenomena of apparition he had observed in the history of court spectacles, in an intersection of proximity (Annährung) and strangeness (Unheimlichkeit)" (170). The identification of the Florentine festivities (and through them Renaissance art) and the Hopi rituals is one of the most difficult elements of Warburg's thought. The journey to New Mexico to the Hopi (the result of which was the lecture on the serpent ritual in the Kreutzlingen clinic) has always been the most debated episode of Warburg's activity.

After returning to Europe in 1927, he began a correspondence with the ethnologist Franz Boas as he still wanted to initiate a study programme combining the disciplines of art history and anthropology. For Warburg the travel was a displacement of knowledge, a technique of anamnesis, "a parable of loosening the grips of melancholy.” By replacing the study of texts and works of art with a "more physical activity" the discipline itself was modified: the research gained an unusual practical significance (181). The dances and rituals of the Hopi were equalled with the ecstatic Dionysian level of Greek culture. Warburg said: "I do not believe I am wrong to consider that gaining a vivid representation of the life and art of a primitive people is a valuable cor- 
rective to the study of any art" (184). The research becomes the reflection of his own personality, whereas the geographical distance is a metaphor of the past (359). Analogy is not only drawn between cultures viewed but between the scholar and the object of his knowledge. Actually in his journal in 1929 a few weeks before his death he calls himself a "psycho-historian" (238). Michaud explains: "like the doll dancers in the Kachina ritual, the researcher gives meaning to something that has no meaning - not in understanding but in reproducing the world in the closed universe of representation" (236) while "abolishing the boundary between world and representation" (232). The Indian rituals just like the Florentine Intermedi were for him scenographic models for transformation of the world into representation (33). Dancers (motions) produce an intermediate being between body and image and transform themselves into representation. This idea is directly inspired by Burchardt who interpreted the Renaissance festivities as "a path leading from life to art whereas in the Oraibi ceremonies Warburg discovered the path from art to life (203).

The exoticon, the unfamiliar object places the cameraman or the art historian into a situation of discovery: to understand that the world operations we set into play cease to be the simple object of research and become its own reflection (36). Warburg's lack of interest concerning styles did not let him question why, for example, the Pueblo Indians did not represent their dances in their visual art. What conditions are there to make a certain type of representation become realizable? Michaud who neglects many aspects of the cultural atmosphere of Warburg's age other than photography and cinema, to which Gombrich devoted two chapters, fails to face the question why the parallel was anthropology for Warburg, and not some other discipline.

Warburg - and, we may add, Michaud as well - treated his studies and his journey on an equal epistemological ground that does not seem to allow any critical approach. As Wind had already remarked in $1931^{13}$ Warburg always showed special interest in intermediate themes not accepted by the code of art history. Michaud claims the constructive idea of creating the Mnemosyne atlas appears to be suggested in the enigmatic phrase "iconology of the intervals" in his journal in 1929 (252). With this remark Michaud definitely means to prove that Gombrich wrongly mentions it was Saxl who played an important role in the genesis of the project. ${ }^{14}$

While Gombrich looks upon the strangely arranged material of the Mnemosyne panels ${ }^{15}$ as on illustrative and practical solutions to represent the interrelations and interactions, 
Michaud treats the execution as a genre or a construction intentionally created exactly like that, something that is informative in itself. In this "ghost story for adults" ("eine Gespenstergeschichte für ganz Erwachsene"), as Warburg called his project, the images assembled this way "function as discontinuous sequences that find expressive significance only when considered in an arrangement of complex interconnections," They are like screens on which the phenomena produced in succession are reproduced simultaneously," like in a cinema (259-260).

A "cinematic mode of thought" or film technique: this is what Michaud calls Warburg's handling of his subject in the chapter on the Mnemosyne to which he adds Freud's motto, "our realm is that of the intervals." The Warburgian idea is that pictures put next to one another will enter into strange and sometimes unexpected relationship with one another. This is an organized network of tensions and anachronisms causing "violent associations, which over time would loose their intuitiveness and become structural" arising "not from simple comparisons, but from rifts, detonations, and deflagrations." They introduce differences within the identical" (255). He calls the images of Mnemosyne "engrams," later "photograms," capable of recreating an experience of the past in a spatial configuration (255). The atlas,
Michaud claims, does not only aim at describing the migration of images through the history of art. The essence is not description but reproduction (272) with this montage of photographic reproduction the question of the transmission of knowledge is submitted with that of its exposition (37). Michaud argues Warburg's visual presentation is a filmic approach.

A scene Michaud explores is the image of the filmic operation itself at the same time, just as the painted scene is the image of representability: each, he claims, is the expression of the process creating it (66). Michaud's idea that here is a relationship between Warburg's project and Eisenstein's "obraznost" theory (282), although interesting seem to lack again explanation at least according to academic conventions. Obraznost ("imageness" or "imaginicity") means a "semantic saturation obtained through the conversation in meaning into a signifying system of several levels."16 Eisenstein's famous theory that the combination of two hieroglyphs is equivalent to their product and not to their sum total (284) is a concept really excitingly similar to the Warburgian idea. But the fact is that no direct influence can be traced, the relationship is only the overlapping in time.

All studies on Warburg mention his lack of interest in stylistic questions, ${ }^{17}$ which is a curious issue although evi- 
dently in connection to his disinterest towards the historical approach. It is still somewhat strange that Michaud treats the problems of visibility and representation concerning the visual appearance of the Mnemosyne project without any reference to visual categories like form, size, or material. The Mnemosyne images are black and white photographic representations (of varying quality) of paintings (originally colourful), of reliefs (necessarily partial) and of architectural details and sculptures (objects originally spatial). Naturally there is no system of any proportion among the representations and no reference to their function. Consequently the pictures are various meaning units from the strict visual point of view which may contradict the idea of any approach of homogenous scope such as film art where the picture units are definitely of equal visual value. 18

On the one hand, the violation of the traditions of academic writing makes it impossible to define the genre of Michaud's book: it is a real "Warburgian montage" made up of elements of knowledge and information, a work of art itself, a book written not on but together with Warburg. On the other, the comparative method comes to exciting conclusions: he suggests that by dislocating the aspect of the spectator (and the function of the scholar) a semantic model is given by Warburg for an interpretation of interrelated and interconnected units of knowledge. In sum, this volume confirms the "prediscursive" purpose of the Mnemosyne project of founding an art history without text, or, alternatively, "the critique of the supremacy of language in the genesis of meaning" (272).

\section{Andrea Hübner}

\section{Notes}

1. "[I]n my role as a psycho-historian, I tried to diagnose the schizophrenia of Western civilization from its images in an autobiographical reflex" (quoted in E. H. Gombrich, Aby Warburg: An Intellectual Biography [London: The Warburg Institute, 1970], p. 303). The affinities of his last and strangest project, the Mnemosyne atlas "are less with works of history than with certain types of poetry, not unknown to the twentieth century where hosts of historical or literary allusions hide and reveal layers upon layers of private meanings" (Gombrich, p. 302).

2. "Warburg selbst wäre gewiss der letzte gewesen, diese Zettel der Publikum zu übergeben. .. Aber als Quelle für den Historiker ist dieser Nachlass eine unerschöpfliche Fundgrube. Wie manche Sammlernaturen, so warf auch Warburg nie etwas weg. . . Der schriftliche Niederschlag von mehr als 45 Jahren ist hier erhalten" (Gombrich quoted in Dieter Wuttke ed., Aby Warburg: Ausgewählte Schriften und Würdigungen [BadenBaden: Koerner, 1992]).

3. Gertrud Bing, Warburg's colleague, who collected and arranged many of his theories he did not write down, decided to approach Warburg's ideas through stylistic 
analysis; see Wuttke, pp. 433-455.

Gombrich in his biography devotes a whole chapter to the very heavy and concentrated Warburgian language full of allusions, which Warburg himself called Aalsuppenstil. Basic terms such as Kulturwissenschaft or Pathosformel gain a definite shift in meaning when translated to English. The word pathos, he claims will mean "suffering" with a stress on "misfortune," whereas in German the focus is more on "grandeur" and "sublimity."

4. His disagreements are elaborated concerning Edgar Wind (75-80), Gombrich $(252,262)$, and Panofsky (143). Only Gertrud Bing receives a positive appreciation (15-16).

5. Michaud is mistaken in stating this. As early as in 1934, Edgar Wind, in his "Kritik der Geistesgeschichte: Das Symbol als Gegenstand kulturwissenschaftlicher Forschung," Kulturwissenschaftliche Bibliographie zum Nachleben der Antike 1 (Leipzig, 1934), had referred to the fact that Warburg went beyond the narrow meaning of iconology. Cf.

Gombrich: "he sometimes referred to this preoccupation as 'iconology,' but his iconology was not the study of complex emblems and allegories but the interaction of forms and contents in the clash of traditions" (Gombrich, p. 313). Perhaps there is an oversimplified image about the Warburgian meaning of iconology in everyday usage, although even contemporary university books give a relatively refined assessment such as Gabriele Kopp-Schmidt, Ikonographie und Ikonologie: Eine Einführung (Cologne: Deubner, 2004) pp. 48-49.
6. Wuttke, p. 173.

7. Wuttke, p. 11.

8. See for example Gombrich, p. 57.

9. "[D]ie Kunst wird eine Symptom, ein Ausdrucksträger, für eine spezifische kulturelle Situation" (Kopp-Schmidt, p. $51)$.

10. Wuttke, p. 65 and p. 103.

11. With such remarks the perspective of the book seems to stretch beyond its own scheme by raising theoretical questions concerning the location of the author, intentionality, etc.

12. Pliny mentions that the portraits of Apelles were so perfect that he prophesied "people's future by their countenance" (Michaud, p. 131); i.e. he recreated faces not simply in their present form but also with reference to what they would become.

13. Wind, p. 331.

14. Gombrich, p. 283.

15. The only exhibition organized about the panels of the Mnemosyne was the reconstruction in Vienna in 1994. The catalogue on the basis of which Michaud elaborated his ideas was not complete, it omitted variants and unpublished material. A new, critical edition was published in 2006, two years after Michaud's $A b y$ M. Warburg: Mnemosyne "Materialen" (Munich \& Hamburg: Dölling \& Galitz, 2006) had appeared.

16. Michaud quotes Pietro Montani (p. 284).

17. Gombrich, p. 308.

18. Michaud's associations concerning the comic strip in the Hearst newspapers with Krazy Kat and Ignatz Mouse (287) seem rather absurd. 